\title{
DEVELOPING SUPLEMENTRY SPEAKING MATERIAL IN DIGITAL MEDIA
}

\author{
Yulfi $^{1}$ \\ STKIP PGRI Lubuklinggau \\ Syaprizal $^{2}$ \\ STKIP PGRI Lubuklinggau \\ $\underline{\text { Ummuhanif97451@gmail.com }^{1}}$
}

Submit, 23-09-2020 Accepted, 22-12-2020 Publish, 29-12-2020

\begin{abstract}
The purpose of this research was to develope and validate the suplementary speaking material in digital media for accounting students of SMK Negeri 1 Lubuklinggau. This research used Research and Development Method by applying Borg and Gall Model. There were ten steps, they are (1) research and information collecting (2) planning (3) developing preliminary form of product (4) preliminary field testing (5) main product revision (6) field testing (7) operational product revision (8) operational field testing (9) final product (10) dissemination and implementation.. The subjects were the Accounting students of eleventh grade in academic year 2020/2021. While, for step 6, 8 and 10 were applied by using Google Classroom application in English group of XI Accounting Program. The data showed that there were some problem faced by the students aespecially in finding a speaking book which concerning to accounting program. The teacher also need a book that can help English speaking skill not only for general English. After following the ten steps in R\&D method, started from analyzing, evaluating, revising and trying out, it was concluded that the suplementary speaking material in digital media for accounting students can help them in learning English based on their need. It was proven by the average score of questionnaire (4.35) with very good criteria.
\end{abstract}

Keywords: Developing, Supplementary Speaking Materials, Accounting Students

\section{INTRODUCTION}

English is an international laguage used to communicate among people in different language backgrounds. Consequently, this language is very important to be learnt by non native language speakers such as Indonesian. In Indonesia, English is as a foreign language. It is tought at school and not use in public places. This language is also one of important subject lessons from secondary till university level. As the result, Indonesia students are able to master English well.

English is also as suplementary skill for someone. it is a language of communication and required in workplace. If someone has good English skill, it 
means that he has additional point and more chance in getting a job. Such as graduations of vocational high school, they are expert in some of field such as Accounting, they still need English to develop their knowledge and support themselves in the work place. To support this, Indonesia goverment by ministry of education set a rule on Undang-undang No.81A Tahun 2013 about Implementation of curriculum part v, learning English can improve mastery of English for learners' need and to support in development potential of the regions.

This phenomenon argues english teachers to design and develop their own English teaching materials. However, it is not easy for them. They have to set aside their busy time beside preparing lesson plan, choosing appropriate instrument of assessment and others.

For vocational high school, especially accounting major, the course book that suitable to the students' need are not available yet. It is also a problem that must be solved. As the response, the supplementary materials for eleventh grade students should be enhanced.

It is not easy for teacher to seek appropriate materials that suitable to students' need (Masuhara \& Tomlinson, 2008). This research expected to help the teacher in finding sufficient supplementary material for speaking skill that suitable to Curriculum 2013. Then, the teacher can use this supplementary book as additional source in teaching speaking. Additionally, the students can more enhance and improve their speaking skill by using this supplementary book.

Developing supplementary material in English teaching and learning is an interesting topic to be discussed. Many researchers have analyzed it. Aisyah, et.al (2014) the result of this research was in the part of students' responded background it was found that the students have a lack experience about learning speaking English especially in nursing vocational. In the target needs and learning needs showed that the students needed materials for speaking which were attractive and interesting and based on nursing vocational. The product of this study was supplementary English speaking materials for nursing vocational.

While, Efrizal (2015) this research shows that Almost of second year students of senior high school at An-Nur Islamic boarding school of Malang, East Java, encountered many problems in speaking activity. The main problem was there were not appropriate teaching English speaking materials that give big portion and opportunity for the students to speak actively and freely in order to support teaching and learning process of English speaking. Concerning these problems, a set of supplementary teaching English speaking materials for the students based Communicative Language Teaching needed to be developed. In this research, the researcher employed the procedures: conducting need assessment, developing supplementary materials, conducting expert validation, revising the materials, trying out the materials, and revising the materials. The 
product of this research is seven units of supplementary teaching English speaking materials for second year students of senior high school at An-Nur Islamic boarding school of Malang, East Java.

Hanswati, et.al (2018) they developed supplementary English reading material for vocational school students. This research used R \& D (Research and Development) method. The data were gathered from a number of sources, including students' need analysis of English reading materials in grade $\mathrm{X}$ in the students' book of 2013 curriculum, supplementary development of the English reading materials for computer networks students, and expert validation of supplementary English reading materials and students' response after used the supplementary English materials.

Still discussing about the related research, developing supplementary Englsih reading material was done. Febriani (2015) showed her research result that English teaching and learning process in MAN 03 Malang especially MAKBI (Madrasah aliyah keagamaan bertaraf International) program encountered many problems in reading activity since they were derived from religious program that is but they has less familiarity to English Islamic reading material and only got general material in English. The main book that used by the English teacher in teaching English has not attract students interest and provide less variety in teaching reading process with uninteresting illustration. This materials using Genre based approach that is in line with the school curriculum. In this research, the researcher employed the procedures: conducting need analysis, developing supplementary materials, conducting expert validation, revising the materials, trying out the materials, and revising the materials. The product of this research is three units of supplementary reading materials for eleventh year students of senior high school at MAN 03 Malang, East Java.

Still in line, Developing English Supplementary Speaking Materials Through Instructional Conversation was done by Nurhidayat \& Rofi'i (2019). The finding shows that the product relies much on the content of $\mathrm{KD}$ in 2006curriculum and the researcher expected the students need to improve speaking since they have opportunity to speak English.

Not only focus on one skill, Murti \& Floriasti (2018) have developed supplementary materials for two skills, namely listening and speaking. The products of this research were a student book and a teacher book of supplementary listening and speaking materials for grade $\mathrm{X}$ students of Senior High Schools. The units were developed by referring to the steps of task-based instruction. Each unit consisted of Share It!,Vocabulary Builder, Let's Practice!, Let's Listen and Speak Up!, Let's Take Action!, Challenge Me!, Time to Sum Up!, Self-Reflection, and Break for Fun. 
The research conducted by team was different with the previous researches. This research was focus on the developing supplementary speaking material for accounting students of SMK. The supplementary speaking materials was designed by using digital media that can help the teacher and students in online class of English teaching and learning students. R\&D method by Borg and Gall (1983) was applied in this research by conducting tenth steps, namely (1) research and information collecting (2) planning (3) developing preliminary form of product (4) preliminary field testing (5) main product revision (6) field testing (7) operational product revision (8) operational field testing (9) final product (10) dissemination and implementation. Thus, it is necessary for the team to develop supplementary speaking material in digital media for accounting students at SMK based on Curriculum 2013.

\section{LITERATURE REVIEW}

\section{Teaching English as Foreign Language}

English is an international language. Therefore, so many people around the world learn and use it for communication. But it has classification in every country around the world based on the use of English such as Indonesia uses English as Foreign Language (EFL) and it is only taught in a classroom, not in daily conversation.

According to Kirkpatrick (2007), the most common classification of English, especially in the language teaching world, has been to distinguish between English Native Language (ENL), English as a Second Language (ESL), and English as Foreign Language (EFL). EFL occurs in countries where English is not actually used or spoken very much in the normal course of daily life. In these countries, English is typically learned at school, but students have little opportunity to use English outside the classroom and therefore little motivation to learn English. China, Indonesia, Japan, and many countries in the Middle East are countries in which English is said to operate as an EFL.

Moreover, being an international language, English plays an important and crucial role in many people's life. It is used for different purposes in social, education and social life. For this reason, English language students try to acquire, use and master it as much as possible to be effective speakers. English language teachers should provide students to frequently interactive activities in their classrooms. Students feel secure, motivated and willingly participate. In studentcentered classes language is primarily a tool of communication. Communication implies interaction and this is done through speaking and interacting with each other (Harizaj 2015).

Indonesia is a country which uses English as Foreign Language. It makes this country had its own methodology on teaching English. Considering the aim of 
learning foreign language, Harizaj (2015) states that students should be involved in communicative activities. Communicative activities mean interaction and communication. Communication in itself includes discussion.

Keeping students active and up to pace teachers may use group discussion methods. Communicative activities would keep students interaction to maximum by exchanging information, giving opinions through cooperative work. Developing discussion, students develop speaking skills, acquire fluency and develop positive effects towards friendship.

\section{Definition of English Material}

Teaching materials are a key component in most language program. There are several definitions of materials proposed by some experts. According Tomlison (2008) material here are anything which are used to help language learner to learn. Materials can be in the form, for example, of a textbook, a workbook, a cassette, a CD-ROM, a video, a photocopied handout, a newspaper, a paragraph written on a whiteboard: anything which presents or informs about the language being learned.

Richards (2006) proposed that material can be a text book, institutionally prepared materials, or teachers ${ }^{\text {ee }}$ own materials. He classified the form of material as : a) printed material such as books, workbooks, work-sheets, or readers: b) nonprinted materials such as cassette or audio materials, videos, or computer-based materials; c) materials that comprise both print and nonprinted sources such as self-access materials and materials on the internet. Richards added the other materials which are not designed for instructional use, such as magazine, newspapers, and TV materials play a role also in the curriculum.

Materials are everything which can help teachers and students in teaching and learning a language. They can be printed or non-printed and they can be instructional material or those which are not designed as instructional materials.

\section{The Concept of Speaking Skill}

Chaney \& Bark (1998) state speaking is the process of building and sharing meaning through the using of verbal and non-verbal symbols, in variety contexts. It is essential part beside listening, reading and writing. The objective of speaking is to improve the students' communicative skill and also the students are able to express themselves in every situation.

Speaking skill is also a productive skill which needs more and more practice and acquisition to obtain a sense of competence and mastery in the language. This skill is one of the language skills which are leant by students. It is considered as one of the most difficult skills because it involves so many different 
elements: pronounciation, grammar, vocabulary, fluency, and comprehension (Brown, 1980).

Furthemore, Haris (1979) mentions five components generally recognized in analyzing of speech process, they are: 1) Pronounciation: including the segmental features vowels and consonants, stress and itonation patterns. 2) Fluency which focus on the ease and speed of the flow speech. 3) Comprehension is for oral communication certainly requires a subject to respond the speech as well as to initiate it. 4) grammar and the last 5) vocabulary.

Thus, speaking is an active productive skill. It is a way in which the language is realized in communicative function. The abiliy to make sentences and to use them in appropriate contxt is the ability needed in speaking skill. It is possible that speaking is quite difficult and complex to be learnt, especially by the students of second language or foreign language (Widdiwson, 1984).

\section{RESEARCH METHOD}

This research applied Research and Development (R \& D) method adopted from Borg and Gall (1983). The steps are (1) research and information collecting (2) planning (3) developing preliminary form of product (4) preliminary field testing (5) main product revision (6) field testing (7) operational product revision (8) operational field testing (9) final product (10) dissemination and implementation. The subjects of this this research were the elevnth grade students of accounting major at SMK Neger 1 Lubuklinggau in academic year 2020/2021. In collecting data, questionnaire and interview were used. Questionnaire was designed in close ended form. There were some steps that applied by using Google Classroom of English class for Accounting students, namely step 6 (field testing), step 8 (operational field testing) and step 10 (dessimination and implementation). It was caused by pandemic situation in Lubuklinggau city that is still in red zone so teaching and learning process applied in online class. While, unstructured interview was used to collect additional data. Thechinique of analyzing the data was by using descriptive qualitative method.

\section{FINDING}

\section{Data from Interview}

The researchers colleced data from some sources, namely need analysis by interviewing the English teacher and the students of eleventh grade accounting major at SMK Negeri Lubuklinggau and analyzing syllabus of English subject for eleventh grade students of vocational school include for accounting major. Interviews were conducted by giving numbers of question to English teacher and the students of eleventh grade of accounting major at SMK Neger 1 Lubuklinggau. 
The English teacher needs teaching material that: 1) the material content should be in variety contexts and for different communication objectives, 2) Suitable to Curriculum 2013, 3) The material content must up to date, 4) interesting to be learnt by the students, 5) there are some practices that make students more active, 6) brief explanation and 7) easy to be applied.

Besides, the result of need analysis identification with students as respondent showed that 1) almost all students state that book is the only source in learning process, 2) the content of material should be interesting, 3) they like book that has many illustations (picture, video, graph and ect) and 4) they need a book that focus on their major, not only for general English.

\section{Data from Analyzing English Syllabus for Vocational Schools Students}

After getting data from need analysis, analyzing syllabus used is the next data sources. This research used syllabus of english subject in curriculum 2013 taht also used in the school. English subject yllabus for eleventh grade students of vocational school include for accounting major consist of nine basic competences that must be achieved by the students. The conclusion of the content materials are 1) expression of offering, 2) expression of asking and giving opinion, 3) invitation, 4) argumentative text, 5) passive voice, 6) personal letter, and 7) cause and effect.

\section{The Result of Feasibilty Test}

There were three experts with different expertise reviewing and validating the product. Each expert was given a validation sheet in the form of a questionnaire with a rating scale containing different items to be reviewed in accordance with their expertise and provided spaces to write their comments to improve the quality of the product.

1. Agus Triyogo, S.Pd., M.Pd. He is one of lecturers of speaking skill at STKIP PGRI Lubuklinggau. He is also ever published a speaking English Book for senior high school level. Content validity and instructional design were hIr focus, here. After reviewing the product, she stated that the product was valid with revision. Generally, he said that the content of the first draft was good, but it still needed some written or visualization that encourage students' speaking skills even more, because the designing of this book is to focused on facilitating students' speaking to communicate well both verbal and non verbal communication. She also suggested to put the eye-catching and colouring pictures to visualize the written contents of this book. They will allow the students more creative to develop their ideas in speaking English. Let them to have Speaking Games or Role Play in pairs or groups also could help them easily to practice and understand the material clearly. 
2. Dr. Dodik Mulyono, M.Pd. The product then was reviewed in terms of media by an expert of media which after reviewing the product, the expert stated that the product was valid with revision.

3. Maria Ramasari, S.Pd., M.Pd. The last expert was focused on the instructional design including 2013 Curriculum. From the validation sheet, there were some comments which needed to be paid attention which were: (1) "Be sure consistent in the use the fonts of books"; and (2) "put the pictures in the sources each chapters in the book.

\section{DISCUSSION}

This part will be discussed about the findings gathered during conducting the research with the steps of R\&D Model by Borg and Gall (1983) used in this research.

1. Research and Information Collecting. Data gathered from need analysis shows that the English teacher and the students need a supplementary materials which can help them in English Speaking Class. They need variety in content, related to curriculum, up todate, completed by illustration and full colour. Their need became guideline for the team in designing the developed supplementary english speaking materials.

2. Planning. The second step is planning. The book was planned to design based on the curriculum of 2013. There are nine materials that conclude in seven chapters. Each chapter discusses one content material. There are two macro parts, 1) definition that contain brief explanation about the material, and 2) practices that contain some students activities in speaking skill. This book is also completed with some illustration and video from youtube.

3. Developing Preliminary Form of Product. From planning mapping, the book was developed. The produced book was a supplementary speaking material for ccounting students at eleventh grade. This book was named "SPEAK UP,

\section{Learn, Practice and Action".}

4. Preliminary Field Testing. This step was aimed to get validation of the first draft from three experts. All of them were lecturers at STKIP-PGRI Lubuklinggau. They were intended to know whether the developed supplementary speaking book was valid or not. Furthermore, it was also intended to get some comments or critiques to improve the quality and validity of the book. In this phase, the validity of the product was reviewed in three different aspects, content (English), instructional design (curriculum), and media (book). After getting some comments and critiques from the experts, the next step was doing revision of the first draft. The revision was related to the all comments, suggestion and critiques given. After getting revision, the developed book was reconsulted to the experts. 
5. Field Testing. Field testing was intended to know the practicality of the developed English speaking book but it is still in small group like in one-to-one evaluation. Field testing, however, involved small group that consisted of six eleventh grade Accounting students of SMK Negeri 1 Lubuklinggau. In this phase, the instruction was conducted in one meeting which the time allocation was 80 minutes. The result showed that the book was effective to be used. However, from this step also was gotten some weaknesses: 1) there are some materials that too complex to be understood by the students, 2) it will be better to print out the book in fullcolor and in hard cover, 3) the language used related to the material should make more detail.

6. Operational Product Revision. After field testing, the next step was operational product revision. The book was revised based on the data gathered in the previous step.

7. Operational Field Testing. The next testing after operational product revision was operational field testing. This step was done by: 1) trying out the book in teaching and learning process. 2) Distributing questionnaire to get data about the practicallity of the developed supplementary book. Trying out was done by using google classrroom in XI AKL 2 (Accounting students) that consisted of thirty students. It was done twice and only in one unit of the book (Expression of Asking and Giving Opinion). After that, a questionnaire that consisted of ten statements are administered. The questionnaire was also given by giving the link of prepared online questionnaire. the result of questionnaire can be seen in the following table.

Table 1. Result Quistionnaire

\begin{tabular}{|c|c|c|c|c|}
\hline Aspect & No & Statement & Score & Remark \\
\hline \multirow{2}{*}{$\begin{array}{l}\text { The } \\
\text { appropriateness } \\
\text { of contents with } \\
\text { students' } \\
\text { characteristic }\end{array}$} & 1 & $\begin{array}{l}\text { The content material is suitable } \\
\text { my English fluency. }\end{array}$ & 4.33 & Very good \\
\hline & 2 & $\begin{array}{l}\text { I am excited to learn the } \\
\text { conversation in English } \\
\text { speaking book for hospitality } \\
\text { for I learn and feel interesting } \\
\text { at the same time. }\end{array}$ & 4.19 & Very good \\
\hline \multirow[t]{2}{*}{$\begin{array}{l}\text { Material } \\
\text { presentation }\end{array}$} & 3 & $\begin{array}{l}\text { Materials presentation is clear } \\
\text { and understandable. }\end{array}$ & 4.00 & Ver \\
\hline & 4 & $\begin{array}{l}\text { The materials conversation is } \\
\text { appropriate with a good } \\
\text { sequence and not confusing. }\end{array}$ & 4.12 & Ver \\
\hline \multirow{2}{*}{$\begin{array}{l}\text { Effectiveness } \\
\text { and efficiency of } \\
\text { the products }\end{array}$} & 5 & $\begin{array}{l}\text { I can use this book to learn at } \\
\text { home and anywhere. }\end{array}$ & 5.20 & Very good \\
\hline & 6 & Learning this book can save & 4.33 & Very good \\
\hline
\end{tabular}




\begin{tabular}{lcllc}
\hline & \multicolumn{3}{l}{ my learning time. } & \\
\hline \begin{tabular}{l} 
Attractiveness $\begin{array}{l}\text { I enjoy using this book when } \\
\text { of the products }\end{array}$ \\
\cline { 2 - 4 }
\end{tabular} & $\begin{array}{l}\text { learning in English subject. } \\
8\end{array}$ & $\begin{array}{l}\text { The book makes me motivated } \\
\text { to learn in English subject. }\end{array}$ & G.00 & Very good \\
\hline Media quality & $9 \begin{array}{l}\text { Font and picture in this book is } 5.33 \\
\text { clearly displayed. }\end{array}$ & Very good \\
\cline { 2 - 5 } & $\begin{array}{l}\text { Color used in this book is so } \\
\text { interesting and synchronized } \\
\text { well }\end{array}$ & Very good \\
\hline
\end{tabular}

From the results, it is shown that all aspects in the developed suplementary English sepaking book from: (1) the match between materials and students' characteristics; (2) material presentation; (3) effectiveness and efficiency of the product; (4) evaluation; (5) attractiveness of the products; and (6) media quality were good with the average score 4.39 asvery good criteria.

8. Final Product. After having try out the product and collecting data from questionnaire, the researcher revised the weaknesses of the book. Then, the next step is final product. The developed supllementary english speaking book for accounting students was developed. The book was named "SPEAK UP, Learn, Practice and Action". The researchers hope this book can help the students and english teacher in speaking class activity.

\section{CONCLUSION}

The product of this $R \& D$ research is a suplementary speaking material in digital media for eleventh grade accounting students. One of the students' need was they need an English book that focus on their major, accounting program, not only for general English that the same as English subject for senior high school students. Then, the teacher also needs a supplementary speaking book that can support teaching and learning process in the classroom. This developed book has been checked, evaluated, revised and tried out in a class only. And the result showed that it got very good responses from the students and the teacher. 


\section{REFERENCES}

Aisyah, N.P, Moon, O., \& Karmila, M. (2018). Developing Supplementary English Speaking Materials For Nursing Vocational School, European Journal of English Language Teaching, 4(1)

Borg, W. R. and Gall, M. D. (1983). Educational Research : An Itroduction (4th ed). London : Longman Inc.

Brown, H.O. (1980). Principles of Language Learning and Teaching. Englandwood Cliffs, NJ: Practice Hill. Inc.

Chaney, A.I \& Burk T.L. (1998). The Practice of English Language Teaching. Edinburgh Gate: Longman.

Dedi, E. (2015). Developing Supplementary Teaching Speaking Materials Based On Communicative Language Teachingfor Second Year Students of Senior High Learners of MAN 03 Malang Based On Genre Based Approach, Journal of Linguistics and Language Teaching, 2(1), 123-136

Eka, N., \& Agus, R. (2019). Supplementary Speaking Materials Using Task Based Language Teaching for Primary Schools In Yogyakarta Context, Vision journal for Language and Foreign Language Learning, 8(2), 55-67

Febriani, H. (2015). Developing Supplementary Reading Materials for Islamic School at An-Nur Islamic Boarding School of Malang, East Java, Indonesia, Linguistics Journal of Liguistics And Language Teaching, 2(2), 99-1112

Hanswaty, N., Hasanudin, F., Rasuna, T. (2018). Developing supplementary English reading materials for Vocational High School, International Journal of Humanities and Innovation (IJHI), 1(2), 99-105

Harizaj, M. (2015). Discussion As An Active Learning In EFL. European Scientific Journal. 11(16) : 231 -236.

Harris, D.,P. (1979). Testing English As Second Language. New York. McGraw Hill Inc.

Kickpatrick, A. (2007). World Englishes : Implication For International Communication and English Language Teaching. Cambridge : Cambridge University Press.

Masuhara, H., \& Tomlinson, B. (2008). Materials for general English. English Teaching Materials: A Critical Review, 17-37.

Nawangsari, A.,M, Tri, W.,F. (2018). Developing Supplementary Listening AndSpeaking Materials For Grade X Students of Senior High Schools, English Language Teaching Journal, 7(7), 495-500

Retno, B.,W. (2019). Supplementary Speaking Materials Using Task Based Language Teaching for Primary Schools In Yogyakarta Context, Journal Of English Language and Pedagogy, 2 (1) 77-88

Richards , J.C. \& Rogers, T. S. (2006). Curriculum Development in Language Teaching. United States of America: Cambridge University Press.

Tomlinson, B. (2008). English Language Learning Materials. A critical Review. London New York

Widdowson, H.G. (1984). The Principles of English Language Teaching. Edinburgh Gate: Longman. 